Eliana Navarro

\title{
HUESPED NOCTURNO
}

¿Vienes de dónde, viento?

¿De los grises barrancos

donde las quilas tejen su maraña?

$¿$ De los oscuros montes, fatigado

de agitar avellanos, maitenes, araucarias?

$¿$ De las lomas abiertas donde el trigo

te cuchichea efímeras palabras?

¿De dónde vienes, huésped adorado,

a detenerte junto a mi ventana?

iAh!, si contigo en esta noche

pudiera irme,

en tu carruaje de invisibles alas!

¿Me llevarías por las altas copas

de los pellines, sierra adentro,

por entre los pulidos campanarios

y sus locas agujas extasiadas,

bebedor de rocío, embaucador de juncos, rondador de balcones, besador de hojarasca?

Entra, divino amigo pendenciero, desgarra con tus manos olorosas estas cortinas rancias,

sube aullando por las escaleras, estremece las lámparas,

derriba estos retratos amarillos, en las alfombras baila

y que baile contigo toda la porcelana, los chales incoloros de mis tatarabuelas, el reloj lento, lento y su lenta, lentísima campana.

Con tus manos de duende, y con tus pies de duende, desgarra este silencio, esta sombra, esta nada. 